\title{
Z perspektywy Zachodniej Kanady o akademickich programach języka i literatury polskiej
}

\author{
About academic programs of Polish language and \\ literature from the perspective of Western Canada
}

\author{
|Bożena Karwowska \\ University of British Columbia
}

\begin{abstract}
This article discusses the current situation of courses in Polish language and literature at North American universities. Diminishing interest in Polish culture, caused by a variety of factors, has resulted in limited offerings of courses on this subject. The common fusion of Slavic and German Departments in North America does not help to reverse this trend. In current years, however, there has been a growing interest in Polish-Jewish themes. This, in turn, might lead to a renewed interest in Polish courses; for instance, the Polish language can be taught not simply with heritage students in mind but also as an important language for reading Holocaust testimonies.
\end{abstract}

Key words: Polish language studies, Polish-Jewish themes, Polish language

Streszczenie: Tematem artykułu jest sytuacja kursów języka i literatury polskiej na uniwersytetach w Ameryce Połnocnej. Zmniejszająca się liczba studentów zainteresowanych zajęciami z kultury polskiej, będąca wynikiem wielu czynników, prowadzi do ograniczania kursów. Sytuacji nie pomaga łączenie wydziałów slawistycznych z germanistycznymi. W ostatnich latach wzrasta natomiast zainteresowanie tematyką polsko-żydowską, co może pomóc w rozwinięciu np. lektoratów językowych nie tylko jako kursów skierowanych do odbiorców poszukujących tożsamościowych wartości języka, ale także polszczyzny jako języka świadectw Zagłady Żydów.

Słowa kluczowe: polonistyka, tematyka polsko-żydowska, język polski,

Sytuację nauczania języka i literatury polskiej poza granicami kraju, a szczególnie w Ameryce Północnej, obserwuję z perspektywy oddalonego od Europy wybrzeża Pacyfiku. Brytyjska Kolumbia, gdzie mieszkam i pracuję na University of British Columbia od ponad 30 lat, z jednej strony podlega tym samym prawom społeczno-akademickim co reszta świata, z drugiej jednak tworzy swoisty i niepowtarzalny społeczny mikroklimat. Mieszkańcy Zachodniej Kanady wyróżniają się wielokulturowością, która widoczna jest nie tylko w sferze etnicznej, ale także językowej. Choć Kanada jest oficjalnie krajem dwujęzycznym, język francuski jest powszechnie znany jedynie 
w Quebec, pozostałe prowincje zamieszkuje ludność mówiąca na co dzień po angielsku. Kolumbia Brytyjska to prowincja anglojęzyczna, ale w praktyce można ją nazwać wielojęzyczną. W niektórych miastach nie obowiązuje nawet nakaz wywieszania informacji w języku angielskim, a szyldom w językach miejscowych diaspor nie muszą towarzyszyć angielskie przekłady. Na wybrzeżu Pacyfiku mieszka np. największa poza Indiami (a właściwie Pendżabem) społeczność Sikhów i znajdują się miasta, w których wielokulturowość oznacza mieszankę kultur z Chin, Hongkongu czy Tajwanu, a wielojęzyczność to mandaryński, kantoński i dialekt Szanghaju. Na pytanie zaskoczonych taką różnorodnością (a przede wszystkim przewagą tzw. kolorowej ludności) gości z Polski, jak wygląda typowy Kanadyjczyk, najczęściej wskazuję na dowolną stojącą w pobliżu osobę - bo tak właśnie prezentuje się przeciętny mieszkaniec Vancouver i okolic ${ }^{1}$.

Język łączący w przestrzeni publicznej wszystkich mieszkańców to angielski, chciałoby się powiedzieć - ten sam, ale jednak różniący się chociażby wymową (nazywaną tu często akcentem). Ów angielski jednocześnie zdradza pochodzenie rozmówcy, i to w sposób wielowarstwowy, bo odkrywa jednocześnie pochodzenie narodowe i przynależność środowiskową mówiącego. Mieszkańcy Zachodniego Wybrzeża mówią kanadyjską wersją angielszczyzny (różniącą się od brytyjskiej i amerykańskiej), jednak po tzw. akcencie łatwo poznać pochodzenie rozmówcy. Do tego dodać trzeba uproszczenia wypowiedzi wynikające z ograniczonej znajomości gramatyki i zasobu słów wśród pierwszego pokolenia imigrantów. Ta językowa mozaika (dotycząca także szkół i uczelni wyższych) prowadzi do sytuacji, w której studenci miejscowych uczelni niejednokrotnie nadal uczą się swobodnego posługiwania się angielszczyzną, a więc dodanie do programu studiów języka „obcego" staje się dla nich nie lada wyzwaniem. Zostało to zauważone także przez administrację i prowadzi na wielu uniwersytetach do zmian $\mathrm{w}$ podejściu do obowiązkowego zapoznawania studentów z innymi kulturami w ramach ich programów akademickich. Na przykład na mojej uczelni trwają obecnie dyskusje dotyczące zmian w wymaganiach programowych na kierunkach humanistycznych odnośnie znajomości języków obcych, gdyż dla wielu studentów angielski nie jest ich pierwszym językiem. Dochodzi do tego coraz powszechniejsze posługiwanie się programami i serwisami translatorskimi (np. google), co zmniejsza potrzebę uczenia języka np. do celów turystycznych.

Dość specyficzna staje się w tej sytuacji funkcja języka ojczystego przybyszów (imigrantów), gdyż w odróżnieniu od powszechnej angielszczyzny przenosi on cechy tożsamościowe. Jest to o tyle istotne, że język angielski dawno już przestał funkcjonować jako spoiwo narodowe czy też medium przenoszące wartości narodowe. Wyraźna tradycyjna funkcja kolonizacyjna angielszczyzny w świecie postkolonialnym oznacza, że tym samym językiem posługują się ludzie w krajach kulturowo niewiele mających ze sobą

\footnotetext{
${ }^{1}$ Więcej na ten temat piszę w artykule Vancouver: Miasto, Pamięć, Płeć. (Karwowska 2012).
} 
wspólnego, a literatura pisana po angielsku nie tworzy już tego, co Benedict Anderson nazywał „wyobrażoną społecznością”, czyli narodem (Anderson 1986). Nie jest to zresztą tylko sytuacja języka angielskiego, ale także konkurującego z nim o pierwszeństwo w świecie języka hiszpańskiego.

Świat postkolonialny to dominacja języków dawnych kolonizatorów połączona ze współczesnymi wymogami ekonomicznymi i łatwą wymianą informacji, tłumaczeniami on-line oraz migracjami. Uczone często i w różnych wersjach (np. jako angielski brytyjski i amerykański) dominujące języki, na różnorakich kursach ogłaszane są jako „drugi język”, ale także jako „dodatkowy język” - choć w Kanadzie nie spotkałam się z określeniem „języka obcego.” Także konferencje metodologiczne/metodyczne, podręczniki, kursy dla wykładowców nastawione są na masowy rynek nauczania języków budzących znaczne zainteresowanie. Stąd być może w środowiskach związanych z nauczeniem mówi się o tak zwanych LCTL, czyli „less commonly taught languages" (rzadziej uczonych językach), do których zalicza się język polski. Co ciekawe, wszystkie one, w odróżnieniu od wielu bardziej popularnych języków, zachowały funkcje narodotwórcze, czyli przenoszą - zachowane $\mathrm{w}$ samym języku, ale także wyraźne w literaturze - zarówno pamięć wspólną, jak i wartości szczególnie istotne dla posługującego się tym językiem narodu.

Wydawałoby się, że podstawowym problemem związanym $\mathrm{z}$ nauką języka jest pytanie o jego przydatność do porozumiewania się zarówno w sferze publicznej, jak i prywatnej, ale w praktyce to samo pytanie odnosi się także do recepcji literatury poza granicami językowymi jej rodzimych czytelników. Kiedy 10 lat temu pisałam o pożytkach płynących z uczenia literatury polskiej poza Polską dla jej rozumienia przez badaczy w kraju (Karwowska 2013), nie myślałam, że w tak krótkim czasie sytuacja ulegnie tak drastycznym przemianom. Zacznę jednak od przypomnienia tezy, że czytający polską literaturę wielokulturowi studenci kanadyjscy właśnie na podstawie tekstów literackich budują obraz historii Polski, a więc w pewnym sensie powtarzają ten sam proces, który w latach PRL-u charakteryzował polską publiczność literacką, szczególnie tę młodszej generacji. To nie oficjalnie propagowane książki czy nauka szkolna stanowiły źródło informacji na temat historii Polski oraz właściwych dla narodu polskiego wartości, ale przemycane niedopowiedzenia i aluzje, rozmowy w domu i rodzinne wspomnienia. Kształtowanie się obrazu owych wartości i wyobrażenia historii narodowej było więc procesem negocjacji pomiędzy sprzecznymi niejednokrotnie informacjami przekazywanymi w sferze publicznej i domowej, a także zauważaniem aluzji i pominięć. Studenci kanadyjscy często nieznający historii Europy (nie wspominając już o historii Polski), tworzyli własną, wyobrażoną wersję historii Polski stanowiącej tło wydarzeń pokazywanych w filmach lub opisywanych w czytanych przez nich tekstach literackich. W tym sensie powtarzali gest młodych czytelników polskich żyjących w czasach PRL-u. W rezultacie proces ten, zatem także proces przygotowywania 
materiału dla studentów, stawał się istotną lekcją dla historyka literatury polskiej uczącego poza granicami kraju. Obecna wyraźna zmiana, jeśli chodzi o nauczanie, wynika przede wszystkim z sytuacji programów i kursów języka i literatury polskiej, jaka nastąpiła w Ameryce Północnej w ostatnim dziesięcioleciu, choć nie bez znaczenia są także zmiany społeczne w Europie i Ameryce.

Kiedy przyjechałam do Vancouver w 1986 roku, slawistyka była nadal znaczącym (lecz już nie jednym z największych) wydziałem University of British Columbia. Choć minęły już czasy lat 60., gdy każdy student nauk ścisłych musiał uczyć się języka rosyjskiego, rusycystyka nadal stanowiła trzon wydziału Slavonic Studies, z pojedynczymi kursami z języków polskiego i ukraińskiego oraz pojedynczymi kursami literatury polskiej i literatur słowiańskich. Z czasem okazało się, że upadek bloku wschodniego (i ZSRR) oznaczał także schyłek slawistyk, które - podobnie jak na UBC - zaczęły znikać z wydziałów uniwersyteckich w Ameryce Północnej. Mimo że - poza nielicznymi miejscami - już wcześniej polonistyka nie odgrywała większej roli i traktowana była jako tzw. „drugi przedmiot” niezbędny wówczas do uzyskania stopnia naukowego w dziedzinie slawistyki (czy nawet rusycystyki), tematyka polska była $\mathrm{w}$ większym lub mniejszym stopniu obecna na wielu uniwersytetach w Północnej Ameryce. Sprzyjała temu fala emigracji lat 80. i zainteresowanie Polską związane z przemianami demokratycznymi w Europie. Dzieci emigrantów z Polski pojawiły się na zajęciach uniwersyteckich, wzrosło znaczenie miejscowych grup Polonii, zwiększyła się liczba mieszkańców pochodzenia polskiego. Miało (i nadal ma) to znaczenie, gdyż w niektórych kanadyjskich prowincjach (np. w sąsiadującej z Brytyjską Kolumbią Albercie) znaczna liczba mieszkańców posługujących się określonym językiem zobowiązuje lokalny rząd do zapewnienia nauczania „heritage culture and language”, czyli języka i kultury kraju pochodzenia, i to zarówno na poziomie szkoły, jak i uniwersytetu. W rezultacie mogą tam działać normalne szkoły polskie, a nie tylko sobotnie szkoły języka polskiego funkcjonujące poza systemem uznawanej przez państwo nauki szkolnej. W większości prowincji Kanady (i stanach USA) liczy się jedynie zainteresowanie i chęć zapisania się na kursy.

W odróżnieniu od sytuacji na Wyspach Brytyjskich polska emigracja do Kanady i USA nie stanowi obecnie zauważalnej procentowo liczby. Dzieci polskich imigrantów lat 80. dawno już skończyły studia, nie wpływając zresztą zdecydowanie na większe zainteresowanie polszczyzną. Podczas gdy potomkowie powojennych emigrantów lat 40. i 50. XX wieku zasilali kursy językowe jeszcze w latach 90., dzieci emigrantów lat 80. nie stanowiły grupy wyraźnie zainteresowanej uczeniem się języka polskiego i poznawaniem kultury polskiej. W Wielkiej Brytanii po otwarciu rynków pracy dla Polaków na początku nowego milenium nastąpił rozwój wydziałów i kursów związanych z językiem i literaturą polską. W Ameryce Północnej przeważa obecnie tendencja do łączenia dawnych slawistyk z wydziałami języków 
i literatur Europy Środkowo-Wschodniej i dominującą germanistyką. Przy okazji znikają etaty dla polonistów, pojawiają się zatrudniani semestralnie instruktorzy, których rola sprowadza się często do prowadzenia wyłącznie tak zwanych lektoratów.

Niezbyt wiele pozostało też z żywego zainteresowania literaturą polską na uniwersytetach, a szczególnie popularnymi na przełomie wieków Brunonem Schulzem i Witoldem Gombrowiczem, czy współczesną poezją polską, czyli Zbigniewem Herbertem, polskimi noblistami - Czesławem Miłoszem i Wisławą Szymborską. Na wybrzeżu Pacyfiku od kilku już lat nie udaje się zapełnić studentami klasy z literatury polskiej i filmu, a zbyt mała liczba chętnych prowadzi z czasem do likwidacji kursu. Okazuje się, że nawet jeśli literatura polska spełnia nadal ważne funkcje tożsamościowe, przenoszone przez nią wartości nie zawsze są interesujące dla odbiorców spoza środowisk Polonii. W wielu ośrodkach akademickich kursy z literatury polskiej zmieniają się w kursy z kultury, obejmując także film polski (lub prezentując dorobek np. Kieślowskiego czy Polańskiego), ale i tak skonstruowane zajęcia budzą coraz mniejsze zainteresowanie studentów. Dodać trzeba, że zdecydowana większość kursów podejmujących tematykę polską skierowana jest do studentów, których programy studiów niewiele mają wspólnego z programami slawistycznymi. Studenci wybierają te kursy przeważnie jako „electives”, dowolnie wybierany kurs wzbogacający obowiązkowe przedmioty ich głównego programu studiów (jak np. historia, ekonomia czy nauki polityczne).

Mniejsze zainteresowanie studentów kursami o tematyce polskiej częściowo związane jest z niewielkim obecnie zainteresowaniem Polską i jej znikomą rolą w przemianach polityczno-społecznych Europy. W roku 1986 pytania o Solidarność i Polskę pojawiały się na egzaminach, na kursach uniwersyteckich na wydziale historii, dając mi poczucie, że w Polsce uczestniczyłam w historycznych przemianach o randze światowej. Obecnie pokojowa transformacja i koniec podziału Europy w świadomości społecznej ograniczają się do upadku muru berlińskiego. Solidarności i Polski 1980 roku nikt tu nie pamięta, a obecna Polska nie budzi nawet zainteresowania mediów.

Pozostaje więc pytanie, jak w obecnej sytuacji uczyć języka i literatury polskiej; jakie obszary mogą być nadal interesujące i przyciągające studentów. Na Uniwersytecie Kolumbii Brytyjskiej, częściowo dzięki życzliwemu wsparciu Konsulatu Polskiego, udaje nam się utrzymać lektorat językowy, oferując naprzemiennie Polski 200 i Polski 300 (kursy dla początkujących i średniozaawansowanych). Ponieważ w klasach początkowych znajdują się studenci znający podstawy polskiego, dość łatwojest w pierwszym roku przekroczyć poziom podstawowy. W takiej sytuacji oferujemy kurs na poziomie drugiego roku, umożliwiając tym samym studentom ukończenie w drugim roku nauki języka polskiego na poziomie zaawansowanym. Trudno byłoby jednak odpowiedzieć na pytanie, jakiego języka uczymy, a więc także na pytanie, do czego ma służyć uczony na kursach akademickich język polski. 
Podręczniki, które sprowadzamy z Polski, sugerują uczenie języka przydatnego w sytuacjach domowych i turystycznych. Zmniejszające się pensum dydaktyczne oznacza, że jako profesor zajmujący się pracą badawczą prowadzę mniej kursów niż kilka lat temu, a więc uczenie języka przeszło w ręce zatrudnianych doraźnie instruktorów lub doktorantów.

W odróżnieniu od programów akademickich oferujących jednocześnie zajęcia z języka i kursy z literatury i kultury, lektoraty językowe, szczególnie $\mathrm{w}$ dobie nauczania interaktywnego, łatwo budować wyłącznie wokół tematyki codziennych konwersacji lub sytuacji, z jakimi spotyka się turysta (czy zagraniczny student w Polsce) ${ }^{2}$. Dodać trzeba, że kursy językowe prowadzone są często przez doktorantów, którzy nie są ani przygotowani do podejmowanej roli, ani nie mają wystarczającej potrzeby, czasu i materialnych środków, aby dokształcać się metodycznie. Programy oferujące kursy z literatury, często budzące zainteresowanie studentów przychodzących na lektoraty językowe, sprzyjają planowaniu zajęć językowych w taki sposób, aby ująć w nich także czytanie w języku polskim tekstów literackich omawianych na zajęciach $\mathrm{z}$ literatury $\mathrm{w}$ języku angielskim, a zatem budowanie świadomości przydatności języka w uczestniczeniu w kulturze rodzimej dla owego języka. Dodam tu przy okazji, że kursy z literatury polskiej (niezależnie od ich różnorodnych wariantów) oferowane są w języku angielskim i nie wymagają znajomości polskiego, gdyż wszystkie dyskutowane teksty studenci czytają $\mathrm{w}$ przekładzie. I tu pojawia się pytanie $\mathrm{z}$ jednej strony o niewielką liczbę programów polonistycznych (a nie tylko oferowania lektoratów językowych) na uczelniach, z drugiej o nikłe obecnie zainteresowanie literaturą polską w Ameryce Północnej. Choć nagroda Bookera dla Biegunów Olgi Tokarczuk stała się niewątpliwym wydarzeniem 2018 roku, amerykański rynek czytelniczy nastawiony jest raczej na masowego czytelnika zainteresowanego fikcją polityczną i historyczną niż na arcydzieła literackie, a zatem powieść Tokarczuk nie zmieniła generalnego obrazu ograniczonej obecności polskiej literatury w Ameryce Północnej. Wystarczy też spojrzeć na tytuły akademickich pozycji wydawniczych poświęconych tematyce związanej z Polską, aby zauważyć, że książki naukowe (na tematy literackie) pojawiają się po angielsku niezwykle rzadko. Częściowo wiąże się to z ogólnie zanikającym zainteresowaniem tradycyjnym literaturoznawstwem. Można pokusić się o uwagę, że i akademicy, i czytelnicy w równym stopniu wykazują znikome zainteresowanie literaturą polską, a to nie ułatwia pracy amerykańskim polonistom.

Jeśli chodzi o tytuły wydawnicze ostatnich lat związane z tematyką polską, to na rynku anglojęzycznym dominują opracowania dotyczące stosunków polsko-żydowskich, pogromów i mniejszości żydowskiej w Polsce w różnych okresach historycznych ${ }^{3}$. Odpowiadają na to zainteresowanie studentów programy wydziałów, na których prowadzone są kursy literatury i języka

${ }^{2}$ Więcej na ten temat piszą Kinga Kosmala i Erik Houle (2017).

3 Znaczącym wyjątkiem jest wydany niedawno tom Being Poland (Trojanowska 2018). 
polskiego, stąd coraz częściej pojawiają się w akademickiej ofercie kursy o tematyce polsko-żydowskiej lub skoncentrowane na zagadnieniach Zagłady.

Wydziały, na których pracują poloniści, nie są jedynymi, które takie zajęcia oferują - Zagłada jest tematyką zajęć na Wydziałach Historii i Judaistyki. Niewiele z nich dotyka polskojęzycznych źródeł Zagłady, koncentrując się na anglojęzycznych tekstach akademickich i na tak zwanej opowieści świadków. Co ciekawe, generalnie Zagłada nie jest tematyką interesującą studentów zapisujących się na kursy języka polskiego. Na wydziale, na którym pracuję, zajęcia na temat Zagłady są najbardziej oblegane przez studentów, ale nie budzą szczególnego zainteresowania wśród studentów polskiego pochodzenia. Północnoamerykańskie podejście do Zagłady i lokalne praktyki patrzenia na Holokaust jako na wydarzenie związane nieomal wyłącznie z diasporą żydowską pokrywają się z polskim myśleniem o niemieckiej okupacji w kategoriach martyrologii narodowej. Długi cień PRL-u to podział na Polaków i Żydów jako grupy rozłączne, a obecna sytuacja i współczesne polityki pamięci nie sprzyjają zmianie tej sytuacji. Jeśli zaś chodzi o studia nad Zagładą, wydaje się, że podstawowymi językami dziedziny są hebrajski i angielski, a także niemiecki, w którym powstawało wiele ważnych dokumentów dotyczących eksterminacji Żydów i polityki w krajach okupowanych w okresie drugiej wojny światowej. Upolityczniony dyskurs amerykański, stawiający Polaków w najlepszym wypadku w pozycji świadków niechętnych ukrywającym się Żydom, nie sprzyja budzeniu badawczej ciekawości, jeśli chodzi o dokumentację polskojęzyczną. Nawet opublikowanie bezpośrednich świadectw Zagłady, czyli dokumentów zebranych w Archiwum Ringelbluma (pisanych po polsku, hebrajsku i w jidisz), nie doprowadziło do wypracowania wśród szerokiego grona badaczy świadomości, że wielu Żydów zamkniętych w gettach nie tylko było obywatelami polskimi, ale język polski był ich językiem rodzimym, w którym zapisali swoje obserwacje na temat tragedii, jaka ich spotkała.

Otwieram tu - być może - dyskusję, która okazać się może niezwykle istotna dla przyszłości obu dziedzin w Ameryce Północnej - zarówno dla Studiów nad Zagładą, jak i dla studiów polonistycznych, włączając w to naukę języka polskiego. Mam nadzieję, że wszystkie zainteresowane strony uświadomią sobie, jak istotna może być współpraca w zakresie dostępu do dokumentów, zapisków, relacji i wspomnień nie tylko dzięki tłumaczeniom, ale przede wszystkim przez kształcenie polskojęzycznych badaczy związanych ze Studiami nad Zagładą, gdyż wielu Żydów pozostawiło po sobie pisany ślad w języku polskim i opowiedziało historię tych, którzy nie przeżyli. Okazać się to może także silnym łącznikiem z bliskim tej tematyce polem zainteresowań współczesnej literatury polskiej i prowadzić do odnowionego zainteresowania tematyką polonistyczną w środowisku badaczy akademickich oraz wśród studentów. 


\section{Bibliografia:}

Anderson Benedict, 1983, Imagined Communities: Reflections on the Origin and Spread of Nationalism, London.

Karwowska Bożena, 2013, Poza wspólna historia. Historycznoliterackie uwagi na marginesie emigracyjnej polonistycznej dydaktyki, „Ruch Literacki”, nr 4-5, s. 395-403.

Karwowska Bożena, 2012, Vancouver: Przestrzeń, Pamięć, Płeć, „Teksty Drugie”, nr 12, s. 157-173.

Kosmala Kinga, Houle Erik, 2017, Internet-Based Cultural Enrichment in the Polish Language Classroom, "East/West: Journal of Ukrainian Studies", vol. 4, nr 1, s. 111-118.

Nedashkivska Alla, 2017, Introduction: Less Commonly Taught Slavic Languages: The Learner, the Instructor, and the Learning Experience in the Second Language Classroom (A North American Context) , "East/ West: Journal of Ukrainian Studies", vol. 4, nr 1, s. 3-9.

Trojanowska Tamara, et. Al, 2018, Being Poland. New History of Polish Literature after 1918, Toronto.

\section{O Autorce:}

Bożena Karwowska - associate professor na Wydziale Studiów Europy Środkowej, Wschodniej i Północnej University of British Columbia w Vancouver. Jej zainteresowania badawcze obejmują zagadnienia związane z czytelnikiem i recepcją literacką, teoriami feministycznymi oraz literackim opisem Zagłady. Autorka książek: Recepcja krytyczna Czesława Miłosza i Josifa Brodskiego w krajach anglojęzycznych (2000); Ciało. Seksualność. Obozy zagłady (2009), Druga płeć na wygnaniu. Doświadczenie migracyjne w opowieści powojennych pisarek polskich (2013) oraz Kobieta-HistoriaLiteratura (2016). Od 2014 roku we współpracy z Muzeum Auschwitz-Birkenau prowadzi seminarium Świadectwa Zagłady, którego efektem jest tom The More I Know, The Less I Understand (współredakcja z Anją Nowak). Publikuje między innymi w „Tekstach Drugich”, „Canadian-Slavonic Papers”, „Przeglądzie Humanistycznym” i „Ruchu Literackim”. 